\title{
Correspondence
}

\begin{abstract}
'Rate capping' and threat to services
DeAR SIRS

I am writing to draw members' attention to some imminent political changes which will affect in particular the members of the College who are practising child psychiatrists.

A central technique in child psychiatry is the effective use of the multidisciplinary team, and its extension, the multiagency case conference. Repeated enquiries following child care disasters have shown the importance of close intra- and inter-professional collaboration and consultation. Social work collaboration is particularly prominent in our work in socially deprived urban settings in which child psychiatric disorders are almost endemic, and it is in these very areas that the multidisciplinary team is under threat.
\end{abstract}

The financial difficulties of 'rate capped' inner city councils will inevitably result in reductions of social work establishments, with the threat that Directors of Social Services will exercise their powers to withdraw staff from hospital and clinic teams to enable the statutory obligations of Social Services to be met.

Added to this will be the reduction in effective local political opposition to cuts after the abolition of metropolitan councils. Furthermore, those in Social Services Departments which operate a closed shop will probably withdraw their labour in protest, further disrupting multidisciplinary team work.

While it is clear that the Welfare State is being partially dismantled for political and economic reasons, the damage to services is at risk of being compounded by inter-professional rivalry and suspicion engendered by shrinking resources.

I suggest that the College takes the view that the social work contribution to hospital and clinic multidisciplinary team work is not a profligate waste of resources, but consititutes a vital part of the important community treatment and prevention service provided by Child Psychiatric and Child Guidance clinics and departments.

I believe it is our responsibility to protect this service by representing this view at a local and national level.

Peter Hollis

Tavistock Centre

120 Belsize Lane, London NW3

\section{Mental Handicap hospital patients and suitability for discharge}

Dear Sirs

In the Second Report from the House of Commons Social Services Committee' it is stated: 'The Minister must ensure that mental illness or mental handicap hospital provision is not reduced without demonstrably adequate alternative services being provided beforehand ...' At the recent Joint Conference with the DHSS on Mental Health Service Planning, Professor Rawnsley, in summing up, said that in chronic mental disorder with disability, the disability of the long-stay patient is underestimated.

- A preliminary screening procedure sometimes used to survey mental handicap hospital patients is the Wessex Case Register Schedule, ${ }^{2}$ and those who are Continent, Ambulant, with No severe behaviour problems, having self-help skills (Able) and who are Verbal or Literate are classified as CAN $A+V / L$. The individuals in this group can then be looked at further as to suitability for discharge from hospital.

In a large mental handicap hospital members of the nursing staff who were familiar with the patients supplied information to the psychology department and a Wessex assessment was completed for each patient. Three hundred and sixty-nine (36.25 per cent of the total) were placed in the CAN A+V/L category. ${ }^{3}$ In discussing the results with respect to community placement, the report stated that 'success in this is the result of many factors such as family circumstances, medical complications and other problems known to nursing staff ... and it appears that the above figure is an overestimate.' This overestimate can be very significant, largely due to underestimation of disability, especially with regard to behaviour.

A preliminary follow-up by the consultant medical and senior nursing staff found that at least 150 of those in the CAN $A+V / L$ category would be unsuitable for discharge, and many more would be difficult to place in the normal kind of community position (hostels and sheltered housing).

The Joint Conference referred to above contained many requests for more accurate data, and it is to be hoped that future Mental Health Planning will proceed on a more realistic basis than the pious hopes of the last ten to fifteen years.

David A. Primrose

26 Garngaber Avenue

Lenzie, Glasgow

References

1House of Commons (1985) House of Commons Paper 13-1: Second Report from the Social Services Committee, Vol. 1, XI, 223.2 London: HMSO.

2Kushuick, A., Blunden, R. \& Cox, G. (1973) A method of rating behaviour characteristics for use in large scale surveys of mental handicap. Psychological Medicine, 3, 466-478.

3Dickens, P. (1985) A survey of residents in the Royal Scottish National Hospital using the Wessex Case Register Schedule. Health Bulletin, 43, 27-32. Edinburgh: SHHD.

\section{Should hospitals for the mentally handicapped continue to offer weekend respite care?}

Dear Sirs

In Rotherham, short-term care admissions account for over $\mathbf{8 0}$ per cent of the total yearly admissions. Of a monthly average of sixty-one admissions, thirty are for weekend respite care.

These admissions take place in Beechcroft Unit, in the grounds of the District General Hospital in Rotherham, South Yorkshire, and in three hospital community hostels. Together 
they provide 152 beds for the short- and long-term care of the mentally handicapped in Rotherham, which has a population of 255,000. The Local Authority Social Service has few hostels and group homes which together offer a total of less than five short-term care places. The weekend respite care does a lot of good to parents, but what does it do to the handicapped person, the recipient?

The handicapped person may find himself in a strange ward if the weekend respite has not been booked in advance, or if no bed was available in the usual ward by the time the request is made. He is in on Friday and out on Monday. During this time he would daily have come across, at the least, three different care givers and put up with many other clients, some worse than himself in terms of self-care skills, behaviour and the degree of physical handicap. There is just the time to scrutinize the environment, learn a few of its rules and adapt, and then it is 'goodbye'. The chances are he may have seen no doctor, had no physical examination or a routine clinical investigation. His admission is for a social reason: 'the bed and breakfast use of the hospital', as some call it.

The weekend respite does something to the consultant also. The consultant or the doctor in charge of the Unit is left in a dilemma. In Rotherham, most of these admissions are arranged between the community nurse and parents. Medical secretaries book them in liaison with social workers and community nurses in a few other places I know of. For days after their discharge, the consultant may not know of the clients who have been in for the weekend respite. This is particularly true when there are no junior doctors or when the client is on no medication. Should there be a cause for litigation for negligence during the respite care, or an unidentified diabetic who goes into a coma soon after discharge on Monday morning, who takes the responsibility?

In the above instance, the client was in a hospital and under a consultant, at least, on the HMRI (DHSS Return Form). Should the same happen in a Social Services hostel or in a family home accepting handicapped persons for weekend respite care, the judgement of the public or of a coroner would certainly be different.

There is a need for the transfer of the weekend respite care to selected and willing families. The receiver of the care, by constantly using the same family, may stand to gain more benefits. Well staffed small units in Local Authority Social Service hostels may be a second choice, especially where the degree of handicap is not severe. As for the hospital and hostels, short-term admissions for assessment, treatment, training and other respite should continue to be available for the mentally handicapped.

In terms of cost effectiveness, the suggested transfer may not be cheaper; but the handicapped person will stand to gain, his parents breathing space still assured. But until then, some consultants will continue to live with their dilemma. I would welcome comments from colleagues.

B. N. NwULU

Beechcroft

Oakwood

Moorgate Road, Rotherham

\section{Self-mutilation and Klinefelter's Syndrome}

\section{Dear Sirs}

In his recent letter (Bulletin, April 1985, 9, 83), Dr Michael Simpson, writing from Durban, seems to be rather peeved that you are giving space to the correspondence on this subject, to the extent that he asks: 'Why are we discussing this combination at all?'

I presume that he is not really suggesting that you, Sirs, should attempt to censor scientific discussion. My sense is that he is implying that this combination could have arisen by chance. Of course, this is one of the null hypotheses that my colleagues and I would like to test eventually by inferential statistics in the conventional way (Siegel'). However, we are still at the descriptive stage of scientific enquiry, rather than at the hypothesis testing stage.

One of the advantages of having the courtesy of your columns is that we are now able to contact all those who are writing in with further examples. Drs Stawski and Farmer from this department are approaching the correspondents with a systematic list of questions about the characteristics of the patients they have reported. I hope that this revelation will not prevent others from writing in! The answers will then enable us to formulate more precise hypotheses for the statistical analysis.

Your readers could be of assistance in a further way. I am not sure what the exact base rates of prevalence are for Klinefelter's Syndrome, and still less for self-multilation. If anyone could help us with figures for these frequencies it would help enormously.

\section{St Mary's Hospital}

London W2

R. G. Priest
REFERENCE

ISIEgel, S. (1956) Nonparametric Statistics for the Behavioral Sciences. New York: McGraw Hill.

\section{Italian psychiatry}

\section{DeAr SirS}

Italy must have a very different pattern of psychiatric disturbance to that in Britain. I assume from Dr Johl's article (Bulletin, April 1985, 9, 73-74) that psychosis does not occur, and that until liberated by Law No 180, Italian mental hospitals were entirely filled with unjustifiably detained patients with non-psychotic disturbances. If this was the case, then 'Democratic Psychiatry' with its emphasis on self-determination and its lack of reliance on drugs, is to be welcomed.

I suspect, however, that mental illness occurs in Italy just as frequently as it occurs here. The fallacy exemplified by $\mathrm{Dr}$ Johl's article is to treat all forms of psychological disturbance as one and from that premise to argue for a single approach to psychiatric treatment. Dr Johl clearly favours sociological reductionism over biological reductionism, equating the former with democracy, humanitarianism and libertanianism and the latter with professional domination and repression.

Perhaps I am suffering from 'false consciousness' or have been indoctrinated by the medical profession, but I am unable 